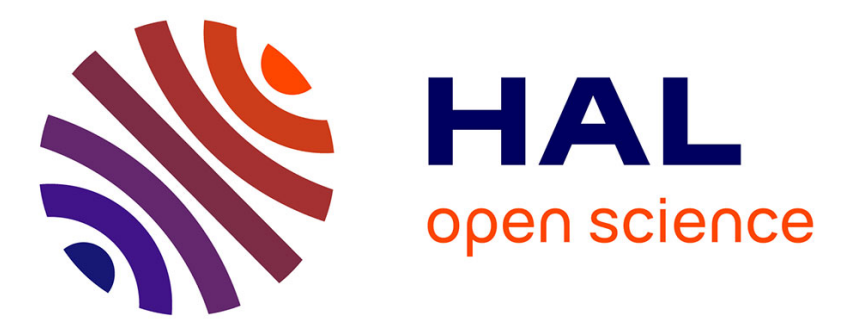

\title{
LAUEX: a user-friendly program for the simulation and indexation of Laue diagrams on UNIX systems
}

Alain Soyer

\section{To cite this version:}

Alain Soyer. LAUEX: a user-friendly program for the simulation and indexation of Laue diagrams on UNIX systems. Journal of Applied Crystallography, 1996, 29 (4), pp.509. $10.1107 /$ S0021889896004736 . hal-01214989

\section{HAL Id: hal-01214989 \\ https://hal.science/hal-01214989}

Submitted on 26 Nov 2015

HAL is a multi-disciplinary open access archive for the deposit and dissemination of scientific research documents, whether they are published or not. The documents may come from teaching and research institutions in France or abroad, or from public or private research centers.
L'archive ouverte pluridisciplinaire HAL, est destinée au dépôt et à la diffusion de documents scientifiques de niveau recherche, publiés ou non, émanant des établissements d'enseignement et de recherche français ou étrangers, des laboratoires publics ou privés. 


\section{Computer Program Abstracts}

The category Computer Program Abstracts provides a rapid means of communicating up-to-date information concerning both new programs or systems and significant updates to existing ones. Following normal submission, a Computer Program Abstract will be reviewed by one or two members of the $1 \mathrm{UCr}$ Commission on Crystallographic Computing. It should not exceed 500 words in length and should follow the standard format given on page 189 of the June 1985 issue of the Journal (J. Appl. Cryst. (1985). 18. 189-190].

\section{J. Appl. Cryst. (1996). 29, 509}

LAUEX: a user-friendly program for the simulation and indexation of Laue diagrams on UNIX systems

\section{ALAIN SOYER}

Laboratoire de Minéralogie-

Cristallographie, Unité associée au CNRS 09, Université Paris 6 et Paris

7, Tour 16, Case 115, 4 place Jussieu, 75252 Paris CEDEX 05, France. E-mail: soyer@Imcp.jussieu.fr

(Received 7 Febrary 1996;

accepted 9 April 1996)

The crystallographic problem: The use of computer programs has considerably simplified the determination of unknown crystal orientation, avoiding the classical method using stereographic projection and Wulff nets. Simulations may also be useful for teaching purposes.

Since the first simulation of a Laue pattern by Krahl-Urban, Butz \& Preuss (1973), many programs have been written for the simulation and/or indexation of Laue diagrams. Some of them are referenced by Marín, Cintas \& Diéguez (1994).

Up to now, it seems that no modern general program dedicated to the processing of diffraction data has been available on UNIX workstations, except the LAUEGEN package of Campbell (1995). However, LAUEGEN is a large program, requiring a lot of disk space, involved in a suite whose aim is the computation of integrated intensities with a view to structure resolution, while LAUEX is only a small simulation/indexation program for everyday work.

Method of solution: LAUEX is a userfriendly program, with an $X$ Window graphical interface. The user enters data in the menus and chooses options by clicking on buttons or moving sliders with the mouse. The data may be saved for later use.

LAUEX performs the following tasks:

(i) Simulation of a Laue diagram, from knowledge of the orientation of the crystal, the cell parameters and the position of the detector. Note that LAUEX is not limited to the transmission and reflection cases, but that the position of the detector may be located anywhere on a sphere centred on the crystal. This feature has been introduced especially for work carried out at a synchrotron. If the structure of the crystal is known, the program may evaluate the intensities of the Laue spots and draws them as spots whose size is proportional to their intensity. The parameters taken into account for this computation are those described by Preuss (1979) (except for the crystal shape), plus the response curve of the detector.

(ii) Indexation of an experimental Laue diagram, by the knowledge of the cell parameters and the position of a number of spots of low index. The indexation procedure has been suggested by Riquet \& Bonnet (1979) and has already been used by Laugier \& Filhol (1983).

(iii) Alignment of a crystallographic direction along an axis of the apparatus (usually the one pointing towards the $X$-ray source), or rotation of the crystal.

(iv) Storing of the simulated diagram as a PostScript file, or printing directly to a laser printer.

On-line help is available if a World Wide Web (WWW) browser is installed on the machine.

Software environment: LAUEX is designed for small UNIX workstations. It has been developed under AIX but may run with other UNIX operating systems. It is written in the $C$ language. An $X$ Window system (Xlib and $X t$ libraries) and OSF-Motif widgets ( $\mathrm{Xm}$ library) are required for the graphical user interface.

Hardware environment: The program is used on an IBM RS 6000 workstation. It runs on other UNIX computers: it has been successfully compiled on an HP 9000/735 and a Silicon Graphics Indigo2. An $X$ Windows display is mandatory, but colour is not necessary.

The memory requirements of LAUEX depend on the maximum number of spots for the simulation; with 3000 spots, a memory size of about 2 Mbytes is needed. The disk space required for the installation of the software is about 6 Mbytes.

For paper output, a PostScript printer must be available.

Program specification: Typical run times for normal utilization are of the order of a few seconds of CPU time on an IBM RS 6000/560. The source code consists of approximately 22000 lines.

Documentation: Documentation of about 1300 lines describes the program use, two examples and the installation procedure. It is available in French as well as in English, as HTML files.
It may also be accessed via the WWW from the software section of the Serveur d'Information National en Cristallographie (SINCRIS) at http:// www.Imcp.jussieu.fr/sincris/logiciel/.

Availability: This program is available of the Internet via anonymous $\mathrm{ftp}$ at the address ftp.Imcp.jussieu.fr in the directory pub/sincris/software/general/laueX. The distribution includes all source code and documentation and is free of charge.

Keywords: Laue diagrams, simulation, indexation.

The author thanks $Y$. Epelboin for the English version of the documentation.

\section{References}

Krahl-Urban, B., Butz, R. \& Preuss, E. (1973). Acta Cryst. A29, 86-89.

Riquet, J. P. \& Bonnet, R. (1979). J. Appl. Cryst. 12, 39-41.

Preuss, E. (1979). Comput. Phys. Commun. 18, 261-275.

Laugier, J. \& Filhol, A. (1983). J. Appl. Cryst. 16, 281-283.

Marín, C., Cintas, A. \& Diéguez, E. (1994). J. Appl. Cryst. 27, 846-852.

Campbell, J. W. (1995). J. Appl. Cryst. 28, 228-236. 